\title{
Aspects of Administration Service Integrated of Sub- District in Semarang City
}

\author{
Bambang Pramusinto ${ }^{1}$, Endang Larasati ${ }^{2}$, Hardi Warsono ${ }^{3}$, Sundarso ${ }^{4}$ \\ \{larasati57@ymail.com $\left.{ }^{2}\right\}$ \\ Universitas Diponegoro, Indonesia ${ }^{1,2,3,4}$
}

\begin{abstract}
Bureaucracy reform implemented to improve the quality of public services. One of the innovations that become a breakthrough is strengthening the sub district as the most bottom of service node. The Government established the policy of the Ministry of Internal Affairs No. 4 in 2010 on PATEN known as Integrated Administrative Services Sub District. Semarang City government responds to this policy by issuing the rules of the mayor number 43 in 2012. PATEN rules govern the various aspects of delegation of authority, infrastructure, service standards, coaching and supervision, and complaints. This article will describe the conceptual and theoretical problems that occur in all aspects of the PATEN in Semarang City. The research method used by researchers is qualitative with triangulation techniques. The results show that the implementation of PATEN policy in Semarang City is not optimal, characterized by some evidence such as the undefeated authority of licensing in the sub-district, infrastructure facilities that are poorly maintained Well.
\end{abstract}

Keywords: Authority Delegation; Sub-District; (PATEN) Integrated Administrative Services of Sub-District; Bureaucracy; and Government.

\section{Introduction}

The demand for public quality improvement as a bureaucracy reform agenda was realized by the regulation of the Minister of Home Affairs No. 04 in 2010 on Administration Service Integrated of Sub-District known as PATEN. PATEN policy is an innovation aimed at empowering the sub district by optimizing the delegation of licensing Services Authority and non-licensing so that community service is closer, easy and affordable in the form of licensing and non-licensing. These are not understanding for the implementation services in the subdistrict to the standards service, coaching and supervision that is not carried out consistently, and the handling of complaints that have not been managed properly. The recommendation suggested by researchers is to perform theoretical and conceptual analysis of the PATEN aspects in Semarang City. In order the delegation of licensing and non-licensing authority can be optimized, the infrastructure facilities are well-maintained and increasing quality, understanding and setting up of service standards, the development of coaching mechanisms and monitoring consistently, and the management of complaints well done.

According to data from the Ministry of Interior of Indonesia Republic, from 514 Districts/Cities, new 228 districts/cities (44.3\%) they are already implementing PATEN's program (www.kemendagri.go.id). It is further explained that by setting up government Regulation No. 17 in 2018 about Sub-District, the Government intends to strengthen the 
quality of service in subdistrict-based communities. Director General of Regional administration of the Ministry of Interior said that the implementation of PATEN still found many problems such as weak support of provincial government, many areas that have not established the PATEN technical team, and low Regional head commitment in fulfilling this PATEN terms.

Semarang City is one of the areas that have not optimized the delegation of licensing authority in the sub district. So far, the district in Semarang City recently carries out one licensing authority in the form of Micro Small Business License (IUMK) and various nonlicensing authority. The licensing authority is still dominated by the Integrated One Door Service Investment Office (DPM-PTSP), covering 119 types of licensing in Semarang City. It is still many licensing services that have not been bestowed on the district encourages writers to conduct research on Aspects of Administration Service Integrated of Sub-District in Semarang City according to Mayor Regulation number 43 in 2012.

The implementation of PATEN in Semarang City is based on the Semarang Mayor Regulation number 43 in 2012. The Mayor Regulation shall govern various aspects of policy including 1) delegation of authority; 2) facility facilities, 3) service standards; 4) Coaching and supervision; and 5) complaints. The following authors will describe the understanding of the various aspects.

\section{Theoretical Framework}

\subsection{Authority Delegation}

Chapters 6 and 7 explain that services held in PATEN consist of licensing and nonlicensing services, which these kinds customized base on mayor's policy. According to Hasibuan [1], authority delegation means giving some work by the authority to the recipient of authority to work on the authority and classifying into seven terms namely: 1) the principle of belief. 2) The principle of delegation to the expected outcome; 3) Periodic chain principles; 5) the principle balance of authority and responsibility; 6) Principle of division of labor; and 7) the principle of the absolute responsibility.

The classic principles of effective delegation according to Kyte, Stoner and Cryer [2], include as follows. 1) The scalar principle, whereby the delegation process must have a clear line of authority flowing level by level from the top level of the organization to the bottom most level to facilitate members of the organization to know to whom they can delegate. From whom they will receive delegation; and to whom they must give accountability. 2) Principle of command unity is stating that every subordinate in the organization should report only to the employer. 3) Responsibilities, authority and accountability, which state that organizations can efficiently use its power: a) Every individual in the organization to perform the task must be authorized sufficiently; b) The individual agrees to accept the liability execution demands.

\subsection{Infrastructure Target}

In Mayor Regulation number 43 in 2012 about the PATEN Standard explained that the infrastructure of PATEN consist of information place, waiting room, counter/registration desk, place of file processing, place of data processing and information, place finalization of the process, place of document submission, place of payment, place complaint handling, and other 
places as needed. Lovelock and Gummesson [3] explained that in order to support good service to customers, organizations need to provide good facilities and infrastructures for customers to consult on technical issues, costs, and administration processes in Taking care of the documents it needs free. Moenir [4] explained that means is all kinds of equipment, work supplies and facilities that serve as the main tools/aids to perform a job.

\subsection{Service Standardization}

The standard concept of Lovelock and Gummesson [3] was emphasized in the ease of filling applications and administrative, flexible, inexpensive, low-cost, and other lightweight requirements, along with the provision of direct information channels Provide the convenience of signs that customers can clearly see.

According to Saggaf et al [5] stated that service standards are measures imposed in the maintenance of services that must be observed by the giver and/or recipient of services that include as follows. a) Service procedures: it is standardized service procedure for the Giver and recipient of services including complaints. b) Time of inquiry: Completion time stipulated from the moment of application to the completion of services including complaints; c) service charge: Fees or service charges including details set forth in the service delivery process. d) Product Services: Results of services to be received in accordance with the provisions stipulated; e) Facilities and infrastructure: the provision of adequate facilities and infrastructures by the implementation of public services; and f) Competence of service personnel: the competence of service personnel must be established precisely based on the knowledge, skills, attitudes, and behaviors required.

Moenir [4] stated that in order for the service to be satisfactory to the person or group of people served, then the perpetrator in this case the officer, shall be able to fulfill the four basic requirements, namely: a) polite conduct; b) How to convey c) delivery time; and d) hospitality.

\subsection{Guidance and Supervision}

Article 14 of Mayor Regulation Number 43 in 2012 governs that construction and supervision of the implementation of PATEN conducted by the Mayor. Article 15 explains that forms of coaching and supervision can be facilitation/mentoring, and evaluation. In Indonesian Dictionary (KBBI) explained that coaching is: 1) process, manner, deed of building (state and so on); 2) Renewal; Enhancements 3) effort, action, and activities undertaken efficiently and effectively to obtain better results. Coaching means renewal or effort, actions or activities implemented powerfully and successfully in order to obtain better results. Coaching is a business, action and activities that are managed effectively and successfully in order to obtain better results [6].

According to Irianto [7], supervision was defined as the process by which the leader wants to observe whether the results of the work performed by their subordinates in accordance with the plan, order, purpose, or discretion A predefined one. Korten [8] explained that a program will be successfully implemented if there is conformity of three elements implementation of the program: a) conformity between programs with the utilization; b) Conformity between programs and implementing organizations; and c) suitability between the group of the utilization with the implementing organization.

According to Siagian [9], there are two supervisory techniques: a) direct supervision, which is the leader of the organization conducting its own supervision over the activities that 
are being carried out. This direct monitoring can form direct inspections, on the spot observation, and on the spot report. b) Indirect supervision is surveillance remotely; this surveillance conducted through reports submitted by subordinates. Lovelock and Gummesson [3] mentioned that customers who are dealing directly would evaluate the friendly and polite attitude of employees who interact with it, the comfort of the waiting room, and other adequate facilities in the form of boxes Complaints or other means.

\subsection{Complaining}

Article 17 of Mayor Regulation about PATEN Corporation explains that the complaint of PATEN maintenance can be done through the suggestion box, Short Message Service, or directly to the District-Head. The complaint according to Prasetya [10] was a verbal or written statement or customer dissatisfaction with the service provided by a service system. According to Hughes and Morgan [11], the process of interaction between Governments and communities is in a very color reform era where government integrity is more assessed in terms of transparency, responsiveness, and accountability.

According to Mardiasmo [12] transparent public service should be informative, open, and published. Responsively is the ability of the organization to recognize the needs of the community, develop the agenda and priorities of services, and develop public services programs according to the needs and aspirations of the community. Dwiyanto [13] stated that a) Embodied in the form of a hospitality attitude and action apparatus in responding to any complaint; b) Exploit complaints from service users as reference or correction material; and c) The ability of bureaucracy apparatus puts service users on the applicable service. According to Dwiyanto [13] public accountability showed whether policies and activities of public organizations are subject to political officials elected by community. Mahmudi [14] explained that the main emphasis of public accountability is the provision of information to the public and other constituents that are the stakeholders (stakeholders) divided into a) vertical accountability; and b) Horizontal accountability.

\section{Research Method}

This type of research uses a qualitative approach, implemented in four sub-districts, encompassing two urban sub-districts (Central Semarang and West Semarang sub-district) and two suburban area districts (Tugu and Tembalang sub district). The retrieval of the informant using Purposive techniques includes the community and the citizens who are accessing the service in four sub-districts of research, and the snow ball technique is possible when conducting research on another informant that understands and involved in PATEN implementation in Semarang. The primary Data in this research was obtained through interviews and observations relating to the implementation of PATEN in sub district. Secondary Data is obtained through the documents in the Sub-district of Semarang City. To obtain the validity of the data used the source and method triangulation techniques. 


\section{Result and Discussion}

Policy Implementation of PATEN in Semarang City refers to the regulations of the Mayor Number 43 in 2012 about the standard of Integrated Administrative Services SubDistrict in Semarang City. The authority delegation policies contained in section 6.7, and 8, facilities stipulated in clause 10.12, the standard of service written in article 11.13, coaching and supervision are found in sections 14.15, and 16, and for complaints written in chapter 17. After conducting a discussion between the facts on the field with various concepts and theories on the PATEN aspects generated research findings as follows:

\subsection{Authority Delegation of PATEN in Semarang City}

The results show that the current authority delegation service in the form of one type of licensing of Micro Small Business (IUMK) and various licensing recommendations to be submitted to DPM PTSP or other agencies. Because only many functioned as a recommendation, the district office is only used as a community service facilitator, and there are not many problems related to licensing. The essence of PATEN to empower the sub district in providing services especially licensing in the lower level has not been realized in Semarang City.

Bases on the concepts and theories presented by Hasibuan [1] related to the authority delegation, there are several factors that have not been fulfill such as the proximity of service to the community. It because of many permits that are much needed the community has not been delegated to the sub-district as well as the implementation of the implementing mayor regulation of PATEN. Permissions are currently needed community such as permits establishing small-scale house building, small-scale billboard permits (banner), permit to set up art workshops, permits establishing elementary school tutoring, permits establishing smallscale tourist attractions, And so on. Some other factors in this aspect have been fulfilled such as the readiness and positive perception of the society to receive delegation, the positive judgment of the public to the service quality, the general clarity of the rules, the conformity of delegation to the task Functions, accountability, training of delegated authority, and control in authority delegation.

\subsection{Infrastructure Facilities in the Implementation of PATEN}

Based on the research findings that has been discussed with the concepts and theories presented by Lovelock and Gummesson [3] and Moenir [4], the facility of PATEN infrastructure in Semarang City in general are decent and good. There was a harmony between the theory presented by Lovelock and Gummesson [3] with the budget policy of Semarang City Government that had a budget of IDR. 200 hundred million to revitalize the District service counter. The district service counter in Semarang City is already equipped with air conditioning, and the room is representative, equipment and complete service facilities.

In addition, not all services in sub district are paid. These policies have an impact on increasing quality of service and community satisfaction. In this infrastructure aspect, only a few parts that need improvement such as cleanliness and layout. The question of other infrastructure found by authors is the low innovation of the sub district adding new facilities such as reading Corner, children's game rides, nursing corner, and so on that can add to the comfort of the community when accessing services. The addition of new facilities also still tends to rely on APBD so it runs slowly. 


\subsection{Service Standardization of PATEN}

Based on the research findings and the results of discussions with the theory and concept of standard services submitted by Lovelock and Gummesson [3] and Moenir [4] in sub district has not found an application that facilitates service. This application is currently an application of the investment service and integrated one door service, to access the services that handled by the service online. Other findings obtained; service personnel competence is still low due to lack of training provided by the city government. Apparatus and service officers need to increase understanding of service standards and service SOP so that both types of documents installed in the service counter. Other factors in this aspect are already well done such as installation of signs and information of service.

\subsection{Guidance and Supervision of PATEN}

Mechanism of construction and supervision of PATEN implementation in Semarang City based on the fact in the field and discussion with some concepts of this aspect theory obtained facilitation findings provided by the Government of Semarang City is already running well. Service technical training is minimal due to the limited number of permissions delegated to the sub-district. Monitoring and evaluation need to be improved quantity and quality so that the results can be utilized to formulate the next PATEN policy, such as to accommodate the wishes of the community in order to access sufficient licensing in the subdistrict.

PATEN implementation is currently not in accordance with the wishes of executive and community. The District-Head and its apparatus are principally prepared to receive the delegation of greater service Authority. People want many services especially the licensing can be completed in the sub district. In fact, this time, the new-delegated permissions one is IUMK.

Direct and indirect supervision as delivered by Siagian [9] ran well. Based on the results of the research in the field related to public supervision refers to theory from Lovelock and Gummesson [3], generally the community provides a positive assessment of the service quality provided by the sub district. The sub-district in Semarang City each year held a survey of community satisfaction to determine the quality of service they provide during this time.

\subsection{Community complaints}

Research conducted by the authors to the aspects of the PATEN complaint in Semarang City based on the discussion of the theory and concept of complaints, obtained the findings of district complaint tools such as complaints box, complaint channel such as SMS, telephone, direct complaints, And Mr. Hendi as the Mayor of Semarang City REPORT app is already running well. Housekeeping needs to be done on the room and the complaint officers who need to be held special in the district. The number of complaints entered relatively small in addition to the burden of authority that more recommendation, condition of infrastructure service of the sub district is already good. Service officers are often act as complaints officers but can be done well and friendly. Management of complaints related to the Sub-district services conducted in accordance with the SOP determined by the Community Complaints Handling Center (P3M) and routinely reported to the Mayor. 


\section{Conclusion}

The results showed some conclusions as follows, 1) on the aspect of delegation of authority, the proximity factor of service has not been fulfilled because new one permits bestowed and other types of licensing dominated by the service. 2) On the aspect of infrastructure, cleanliness, layout, innovation procurement of new facilities with Corporate Social Reasonability scheme is still low. 3) On the standard aspect of service, not yet built service application to facilitate the community and some service officers less understand the concept of standard service-SOP service. 4) On the aspect of coaching and supervision, the results of monitoring and evaluation has not been used as the material of the policy formulation changes PATEN and PATEN program until now has not optimized the delegation of licensing authority in accordance with the expectations of society and implementation. In addition, 5) On the aspect of the complaint, has not been appointed special officers and room complaints.

The recommendation of researchers is, as follows, 1) needs to be optimized delegation of licensing authority, especially those often accessed and needed by the community. 2) The establishment of less infrastructure, increased innovation and networking in developing new service facilities; 3 ) the creation of a sub-district service application, understanding of service standards and SOP. In addition, increasing competence of service personnel 4) Follow up the results of monitoring and evaluation of PATEN for the formulation of subsequent PATEN policies and 5) Sub-district need to appoint officers and hold special room for complaint management.

\section{References}

[1] Z. A. Hasibuan, "Metodologi Penelitian Pada Bidang Ilmu Komputer Dan Teknologi Informasi," Konsep, Tek. Dan Apl., 2007.

[2] M. Kyte, J. Stoner, and J. Cryer, "Development and Application of Time-Series Transit Ridership Models for Portland, Oregon.," Transp. Res. Rec., 1985.

[3] C. Lovelock and E. Gummesson, "Whither Services Marketing?: In Search of a New Paradigm and Fresh Perspectives," J. Serv. Res., 2004.

[4] H. A. S. Moenir, Manajemen Pelayanan Umum di Indonesia. 2010.

[5] S. Saggaf, R. Salam, F. Kahar, and H. Akib, "Pelayanan Fungsi Administrasi Perkantoran Modern," J. Ad'ministrare, vol. 1, no. 1, pp. 20-27, 2014.

[6] W. J. S. Poerwadarminta, "Kamus Umum Bahasa Indonesia, Pusat Pembinaan dan Pengembangan Bahasa." Depdikbud. Jakarta: Balai Pustaka, 1998.

[7] J. Irianto, "Manajemen sumber daya manusia sektor publik di Indonesia: pengantar pengembangan model MSDM sektor publik," J. Masyarakat, Kebud. dan Polit., vol. 24, no. 4, pp. 281-291, 2011.

[8] D. C. Korten, "When corporations rule the world," When Corp. rule world, 1995.

[9] E. S. Siagian, "Public-private partnerships in Indonesia: a comprehensive legal framework of significance to action and analysis," Asia Pacific J. Public Adm., vol. 39, no. 1, pp. 72-78, 2017.

[10] D. R. Prasetya, "Analisis Pengelolaan Pengaduan Masyarakat Dalam Rangka Pelayanan Publik (Studi Pada Dinas Komunikasi dan Informatika Kota Malang)," J. Adm. Publik, vol. 1, no. 6, pp. 1151-1158, 2013.

[11] M. Hughes and R. E. Morgan, "Deconstructing the relationship between entrepreneurial orientation and business performance at the embryonic stage of firm growth," Ind. Mark. Manag., 2007. 
[12] Mardiasmo, Akutansi Sektor Publik. Yogyakarta: Andi, 2009.

[13] I. Dwiyanto, "Kebijakan Publik Berbasis Dynamic Policy Analisys," Gava Media Yogyakarta, 2009.

[14] M. Mahmudi, "New Public Management (NPM): Pendekatan Baru Manajemen Sektor Publik," Sinergi Kaji. Bisnis dan Manaj., vol. 6, no. 1, 2003. 